\title{
THE STUDY OF USING GIS TOOLS IN SUSTAINABLE MANAGEMENT OF SOLAR ENERGY
}

\author{
Adam BUJARKIEWICZ ${ }^{1}$, Małgorzata SZTUBECKA ${ }^{1}$, Jacek SZTUBECKI ${ }^{1}$ \\ University of Science and Technology, Bydgoszcz, Poland
}

\begin{abstract}
Resource efficiency is the primary element of the European Union's 'Europe 2020' strategy for the economic growth. It aims at stimulating economic growth which will be smart, sustainable and inclusive. Proper land use is beneficial to the economic development and it contributes to the improvement of living conditions considering the principle of sustainable development. Geographical information systems are the perfect tools enabling effective spatial planning. GIS technology allows to carry out complex analysis, which enable a comprehensive environmental and urban assessment. Using GIS tools gives also a possibility to assess different variations of land use in the future. The article presents the results of the analyses carried out on the basis of DTM and DSM, which purpose was to assess the potential of solar energy of the selected area. It was shown the possibility of using the roof surface of old buildings in a chosen part of Bydgoszcz to install solar systems on them.
\end{abstract}

Keywords: renewable energy sources, solar energy, GIS

\section{INTRODUCTION}

Reducing the emission of $\mathrm{CO}_{2}$ is a priority for every country in the world. According to the plan of actions leading to the transition into a competitive lowemission economy adopted by the EC in 2011 [5], the European Union expects that the emission of $\mathrm{CO}_{2}$ will reduce by $80-90 \%$ until 2050 . This entails

\footnotetext{
1 Corresponding authors: University of Science and Technology, Faculty of Civil Engineering, Architecture and Environmental Engineering, Kaliskiego ave 7, 85-796 Bydgoszcz, Poland, +48523408639, adamb@utp.edu.pl sztubecka@utp.edu.pl; jaceksz@utp.edu.pl
} 
switching from conventional sources of energy to that which employ renewable energy. In 2020, Poland should generate already $15 \%$ of electric power and heat from Renewable Energy Sources.

The necessity to limit the emission of greenhouse gases has become an incentive for using modern systems which benefit from natural power sources of Earth and the Sun, and the gravitational interaction between planets. At the same time, owing to a dynamic technological growth and gradual reduction of cost, such systems have been attracting growing interest of the society. New power challenges has their contribution to the construction industry. The current direction of development is focused on energy-efficient and zero-energy buildings which generate more energy from renewable sources than they consume during a year.

Renewable energy sources which can be used in the territory of Poland include: solar energy, wind energy, water energy, geothermal sources (hot water, hot rocks) and biomass energy (biogas, biofuels). However, access to such sources is not possible in all places. For example, congested municipal areas impose the application of technologies which have no harmful impact on the environment $[4,7]$.

Due to limited space in cities, the most frequently used Renewable Energy Source is solar energy and wind energy, whereas systems required to collect energy from the said sources are installed on building roofs or - in very few cases - on building facades. In Poland, the following technologies based on Renewable Energy Sources can be considered for installation on building roofs: photovoltaic cells (PV) for generating electric power, solar collectors for heating warm utility water and general heating (ST) and wind plants for electric power generation.

An attempt was made in this article to assess opportunities for the collection of solar energy on building roofs in municipal areas and a solar potential for selected parts of a city characterised by different density and building development was defined.

\section{USE OF SOLAR RADIATION ENERGY IN POLAND}

Solar energy is the primary source of energy for Earth. It is attractive as it lacks side effects, harmful emissions or impoverishment of natural resources when consumed. It can be applied to generate electric power and warm water by using proper collection and accumulation systems [11].

Solar radiation energy use principles and conditions in Poland are regulated by the Act of 20 February 2015 on Renewable Energy Sources [13]. Its purpose is to ensure sustainable economic development while improving energy security and environmental protection. It defines principles and conditions for the 
generation of electric power from renewable energy sources, mechanisms and instruments supporting such generation, etc.

Considering the geographical location, sunlight exposure conditions in Poland (Fig. 1.) are considered good. The vast majority of the country is characterised by the sunlight exposure of more than $1000 \mathrm{kWh} / \mathrm{m}^{2}$ per year. These are mainly coastal areas - up to $1137 \mathrm{kWh} / \mathrm{m}^{2}$ and southern areas $\left(1053 \mathrm{kWh} / \mathrm{m}^{2}\right)$. The values for the Central Poland are approx. $1022 \mathrm{kWh} / \mathrm{m}^{2}$.

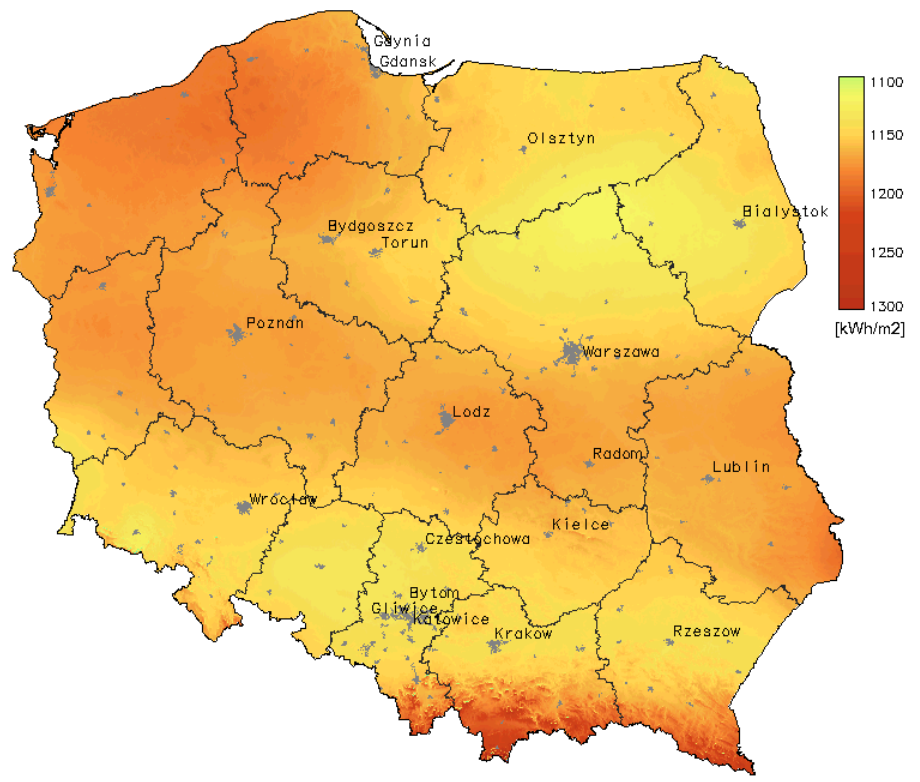

Fig. 1. Yearly sum of global irradiation on optimally-inclined surface in Poland [14]

Despite such high sunlight exposure values, the power of installed photovoltaic systems in Poland in 2016 was only $91.82 \mathrm{MW}$. In comparison to the overall power of Renewable Energy Source systems in Poland (Fig. 2a), it makes up only $1 \%$. However, it should be emphasised that in the last three years there was a rapid growth of sunlight energy generation systems (Fig. 2b). One can expect that the system of state support for this type of projects and an increase of photovoltaic cell performance combined with a reduction of their prices will contribute to further intensive use of this energy source. 
a)
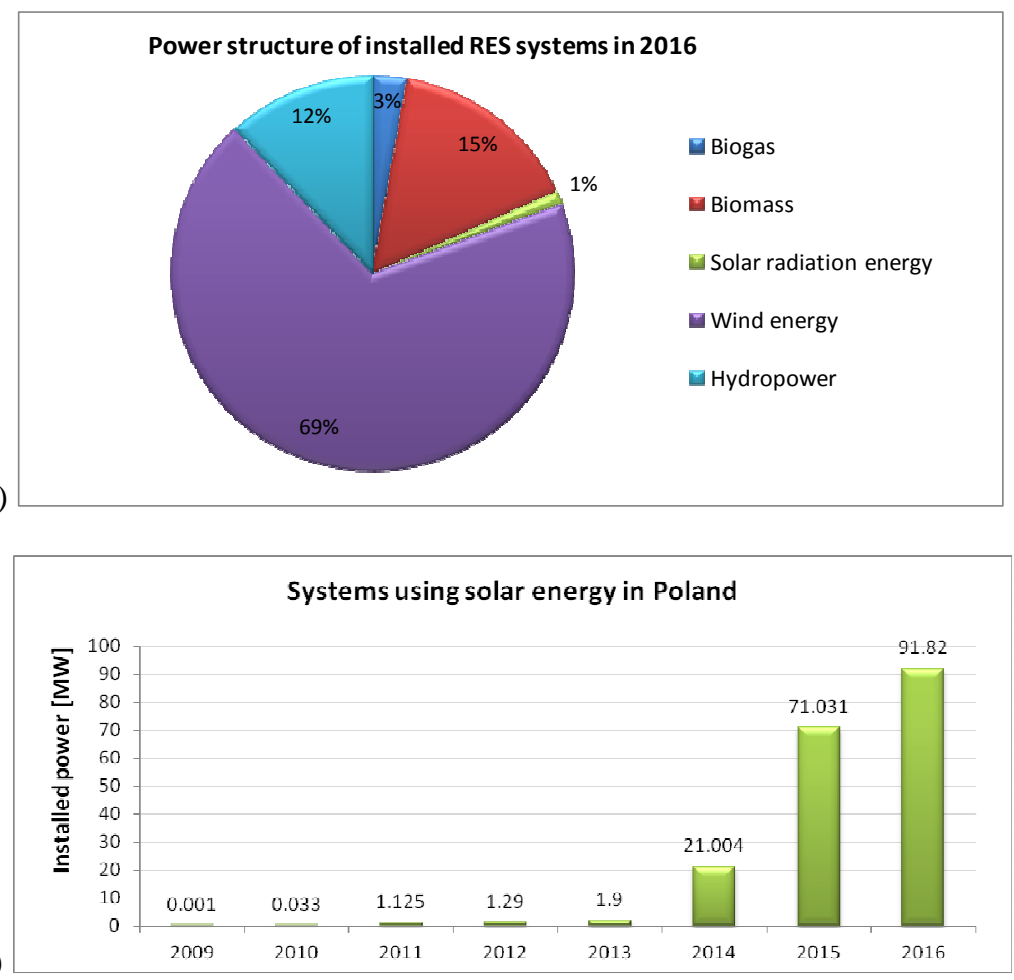

Fig. 2. Power structure of systems installed in Poland (a) and power of systems using solar energy in Poland in the years 2009-2016 (b). On the basis of [12]

\section{AN ANALYSIS OF A SOLAR POTENTIAL FOR A SELECTED PART OF A CITY}

In order to determine opportunities for collecting solar radiation energy, the amount of direct radiation, taking into account climatic conditions of a given area, scattered radiation and exposure time, is calculated for geographically specified areas. Calculation results are presented in the form of solar maps or cadastres which are published on websites, etc. The simplest 'solar geo-portals' use low-resolution climatic data. An example of such website is PVGIS created for Europe and Africa, and for Asia since September 2014. A user of this portal, after entering geographic location, roof pitch and exposure, and type of photovoltaic cells, can receive information on the obtainable amount of energy [9]. Information for city and suburban areas are made available in a similar way. The average amount of energy which can be collected from building roofs is presented on colour maps. Such works present the solar potential of areas, yet they do not provide specific information on the amount of energy which could 
be obtained on a fragment of the building roof or which surface of the roof is suitable for installation of photovoltaic cells.

This encouraged the authors to perform a number of analyses in order to find answers to the following questions: In which parts of cities and from which types of building roofs can we obtain the greatest amounts of energy? How does the solar potential affect the building development and nature? In what way does the energy potential of roofs depend on their shape?

\subsection{Methods and data sources}

Due to limited access to free, undeveloped land surfaces in urbanised arreas, photovoltaic cells can be installed only on building roofs or their facades [11]. Therefore, solar potential maps are created usually for roof surfaces. They are often referred to as solar cadastres. City development, however, is strongly diversified and buildings have roofs of various structures and shapes. Furthermore, depending on the construction period and location within a city, the characteristics of the surroundings, which influences shading of buildings and sunlight scattering, may vary significantly.

Three areas of a different development structure were compared in the analysis of the solar potential for a fragment of the city of Bydgoszcz. These include:

- a fragment of a single-family housing estate (located in the suburbs),

- a fragment of a multi-family housing estate,

- a fragment of the city centre with a historically shaped downtown development (compact buildings).

LiDAR measurement data [10] saved in LAS format files corresponding to 1:1250 scale sheets and covering areas of approx. $0.5 \times 0.5 \mathrm{~km}$ were used for the analysis. The average density of land coverage point clouds for selected areas was 12 points $/ \mathrm{m}^{2}$, whereas the average height error was $0.1 \mathrm{~m}$ (Fig. 3).

a)

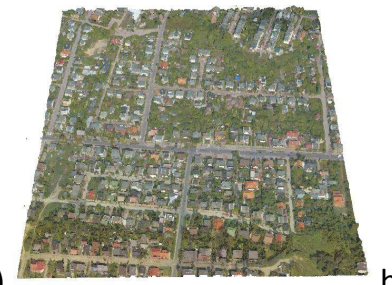

b)

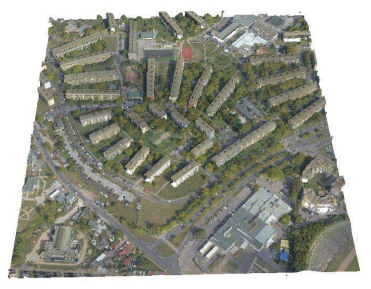

c)

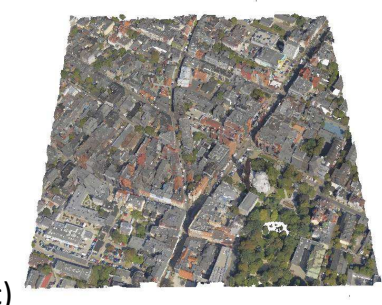

Fig. 3. LiDAR measurement data presented in the form of RGB colour point clouds for a fragment of a single-family housing estate (a), a multi-family housing estate (b) and the city centre (c) in Bydgoszcz

Calculations of the solar potential were carried out with ArcGIS package tools from ESRI, using a methodology described in numerous publications $[1,2,3,6$, 
8, 11]. Fig. 4 shows Digital Surface Models (DSM) for the analysed areas, generated on the basis of Airborne Laser Scanning (ALS) point clouds.

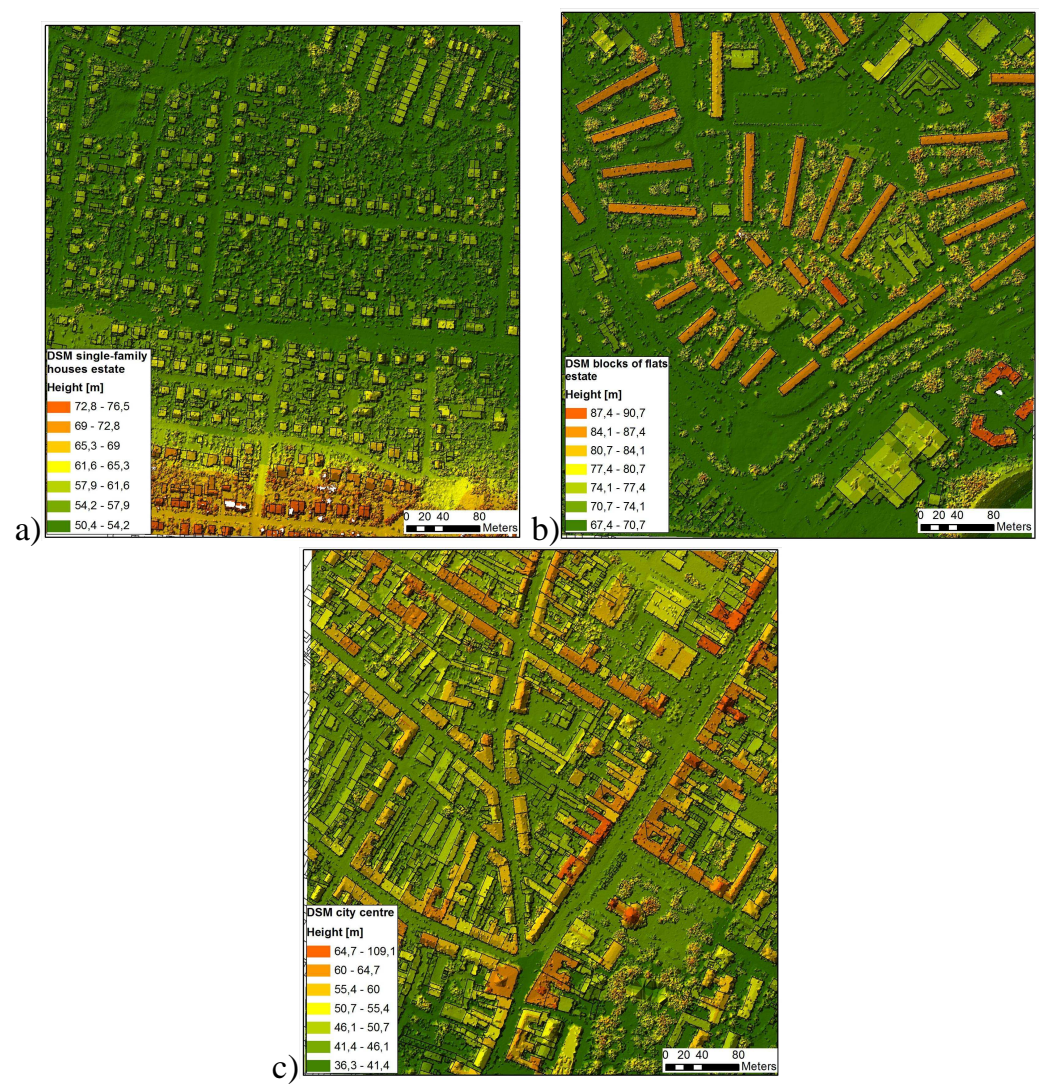

Fig. 4. A numerical land coverage model (TIN) and outlines of buildings for a fragment of single-family housing estate (a), a multi-family housing estate (b) and the city centre

(c) in Bydgoszcz

When measuring the sunlight exposure, a latitude of a given area was taken into account. Moreover, values of radiation scattering from all sky directions, the average atmospheric diffusion rate of 0.3 and the transmission rate of 0.5 were applied. Measurements in a whole year period with a monthly interval were carried out for each area. As a result, the following raster maps were obtained:

- direct radiation time [h],

- scattered radiation $\left[\mathrm{Wh} / \mathrm{m}^{2}\right]$,

- direct radiation $\left[\mathrm{Wh} / \mathrm{m}^{2}\right]$,

- global radiation $\left[\mathrm{Wh} / \mathrm{m}^{2}\right.$. 
In order to determine the solar potential, global radiation (Fig. 5b), i.e. the sum of direct and scattered radiation was considered.
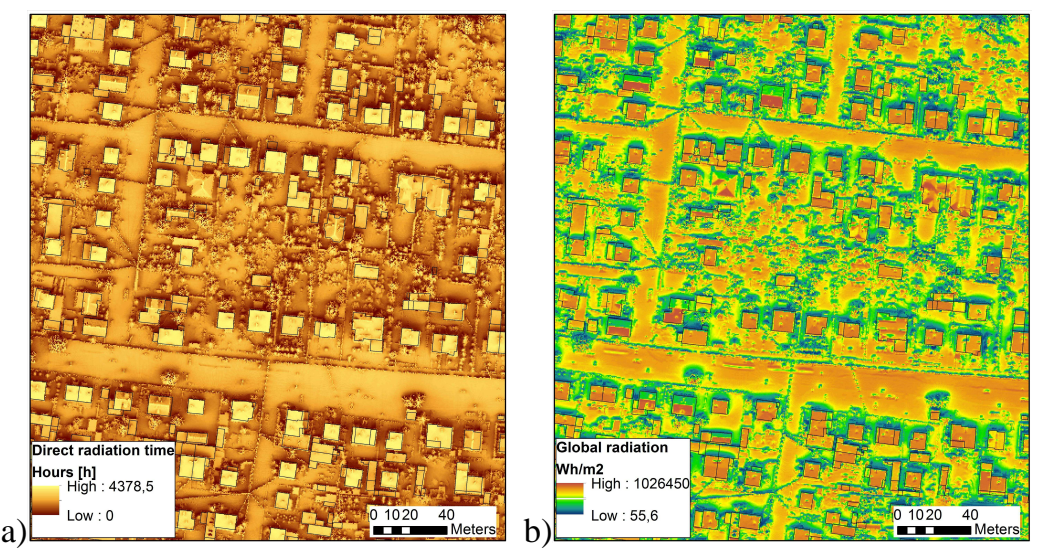

Fig. 5. Results of sunlight exposure measurements on a single-family housing estate in Bydgoszcz: a) direct radiation time $[\mathrm{h}]$, b) global radiation $\left[\mathrm{Wh} / \mathrm{m}^{2}\right]$

Presentation of the solar potential of a developed area comes down to determining what global radiation occurs on building roofs during the whole year. For this purpose, fragments of the raster in the building outlines must be separated. Results of such a spatial analysis are shown in figures $6-\mathrm{a} 1, \mathrm{~b} 1, \mathrm{c} 1$. To ensure higher transparency of a solar cadastre, the solar potential is usually presented on generally available geoportals as average annual global radiation for the entire roof surface. Figures $6-a 2, b 2, c 2$ present the result of zone statistics of solar data, which demonstrates mean values for roof surfaces on a single-family housing estate, multi-family housing estate and the city centre.
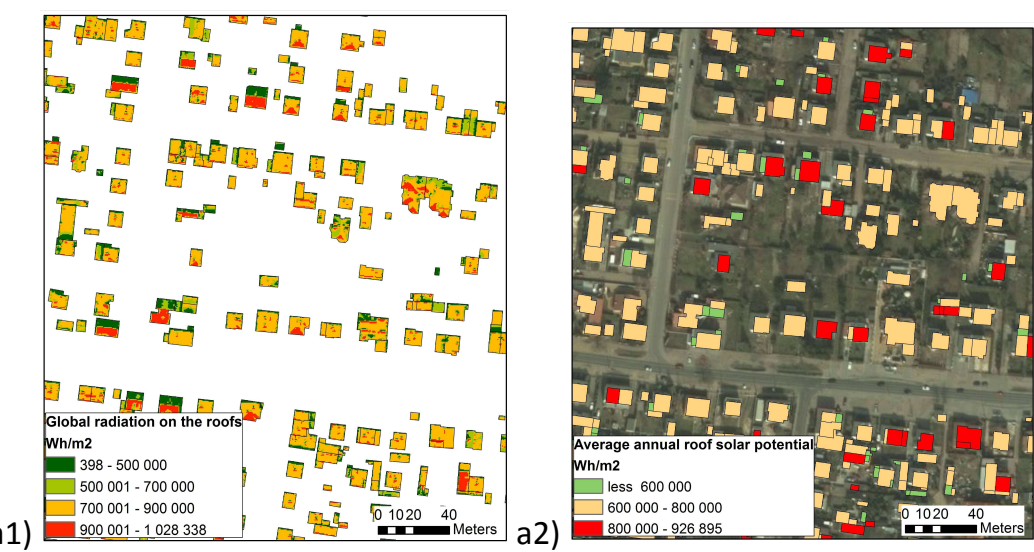

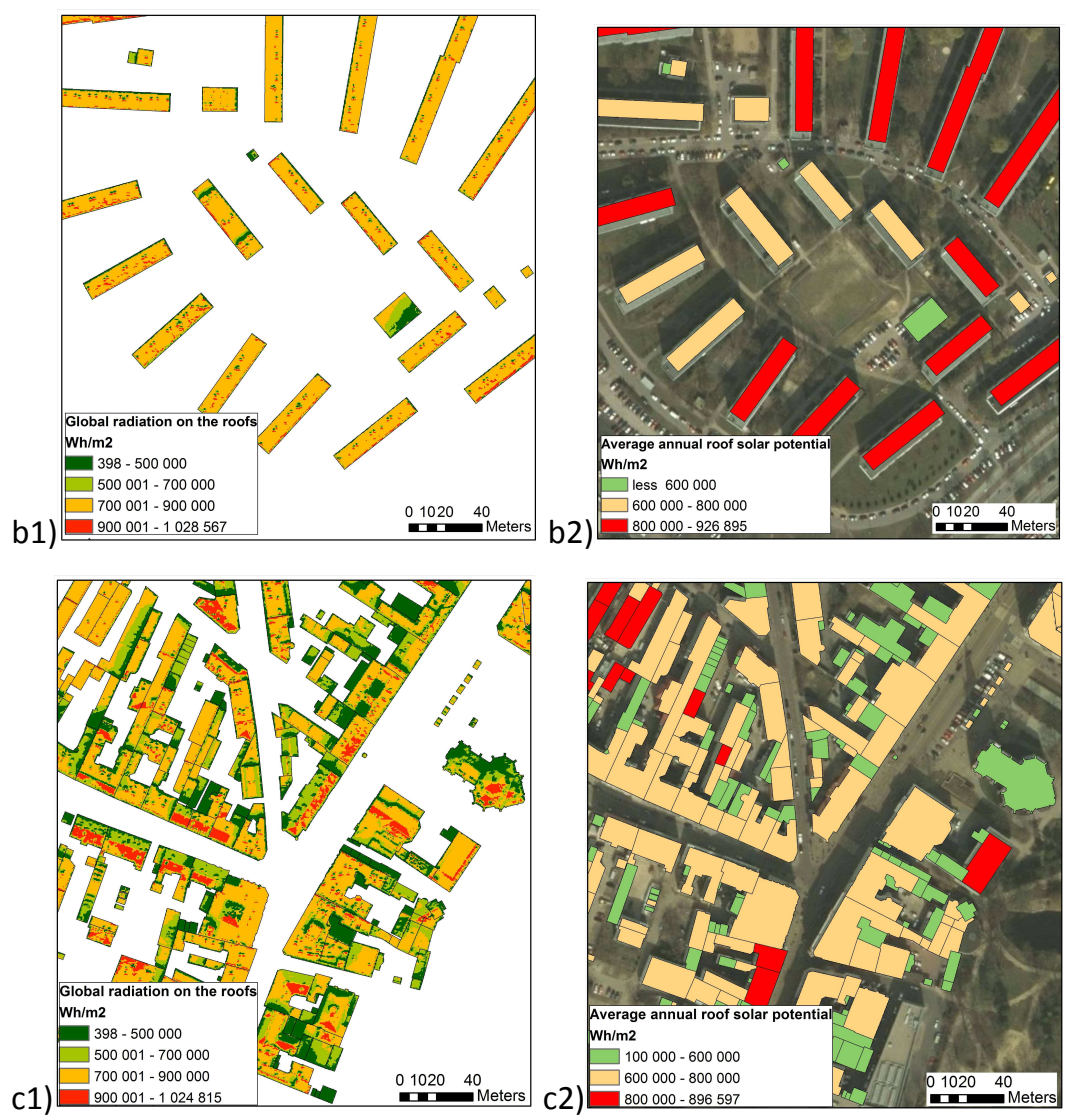

Fig. 6. Global radiation on building roofs (1) and solar potential of roofs (2) in $\mathrm{Wh} / \mathrm{m}^{2}$ in Bydgoszcz: a) a single-family housing estate; b) multi-family housing estate; c) city centre

\subsection{Result analysis}

\section{Ratios for fragments of a city of different development density}

Urbanised areas cover surfaces of different intensity and development density. Assuming that solar panels are installed always parallel to the roof slope, it is possible to compare amounts of solar energy generated in districts of different development. Comparative calculations were made for three equal areas corresponding to the ranges of LiDAR data sheets at a scale of 1:1250. The first area was separated on a single-family housing estate, the second one on a fourand five-level multi-family housing estate, and the third one in the city centre 
with compact tenement housing development. Table 1 presents total annual values of radiation reaching the surface of roofs within the said areas.

Table 1. Results of measurements of the solar potential of the analysed areas

\begin{tabular}{|l|c|c|c|}
\cline { 2 - 4 } \multicolumn{1}{c|}{} & $\begin{array}{c}\text { Single-family } \\
\text { housing }\end{array}$ & $\begin{array}{c}\text { Multi-family } \\
\text { housing }\end{array}$ & $\begin{array}{c}\text { Downtown } \\
\text { development }\end{array}$ \\
\hline $\begin{array}{l}\text { Total radiation for the } \\
\text { surface of all roofs }[\mathrm{GWh}]\end{array}$ & 32.1 & 34.1 & 81.3 \\
\hline Total roof surface $\left[\mathrm{m}^{2}\right]$ & 44,356 & 43,878 & 123,014 \\
\hline $\begin{array}{l}\text { Average annual solar } \\
\text { radiation }\left[\mathrm{kWh} / \mathrm{m}^{2} \text { ) }\right.\end{array}$ & 689 & 725 & 569 \\
\hline
\end{tabular}

On the basis of the analysis performed, it was found that total surfaces of roofs for a single- and multi-family housing areas are similar, the difference does not exceed $1 \%$. On the other hand, the difference between the average annual solar radiation calculated for roofs of buildings within these areas is $35 \mathrm{kWh} / \mathrm{m}^{2}$. The total amount of radiation for all roofs in a single- and multi-family housing district differs by $6 \%$ in favour of multi-family development. Thus, one can claim that at a similar surface of the roofs in both analysed areas, more favourable conditions to obtain solar energy are provided by multi-family housing development. It is caused mainly by the development height difference (no obstacles by trees on multi-family housing estates) and roof shape - multifamily buildings usually have flat roofs.

For the area located in the city centre, where compact tenement development is predominant, the total roof surface is three times greater than in the other areas, and the total value of radiation for all roof surfaces is approx. 2-3 times greater. The average solar radiation for one roof is significantly lower than in single- and multi-family housing development.

Table 2. Results of measurements for roofs of the average solar potential above $800 \mathrm{kWh} / \mathrm{m}^{2}$ on the analysed areas

\begin{tabular}{|l|c|c|c|}
\cline { 2 - 4 } \multicolumn{1}{c|}{} & $\begin{array}{c}\text { Single-family } \\
\text { housing }\end{array}$ & $\begin{array}{c}\text { Multi-family } \\
\text { housing }\end{array}$ & $\begin{array}{c}\text { Downtown } \\
\text { development }\end{array}$ \\
\hline $\begin{array}{l}\text { Total radiation for the } \\
\text { surface of all roofs [GWh] }\end{array}$ & 6.3 & 14.4 & 7.9 \\
\hline Total roof surface $\left[\mathrm{m}^{2}\right]$ & 7,732 & 17,487 & 9,679 \\
\hline $\begin{array}{l}\text { Average annual solar } \\
\text { radiation }\left[\mathrm{kWh} / \mathrm{m}^{2} \text { ) }\right.\end{array}$ & 824 & 825 & 822 \\
\hline
\end{tabular}

Considering the fact that investing in one building is cost-effective when solar panels are installed on roofs of properly high solar potential, additional 
calculations were made which covered only such roofs for which the average annual potential exceeds $800 \mathrm{kWh} / \mathrm{m}^{2}$ (Table 2).

If we consider only roofs of the average solar potential above $800 \mathrm{kWh} / \mathrm{m}^{2}$ (Table 2) when comparing individual areas, downtown development appears to be less favourable for obtaining energy from photovoltaic cells than multifamily housing development. In fact, it is more advantageous than single-family housing development. It is caused mainly by different development density on these areas. The average solar radiation for roofs of a high solar potential is at a similar level of 822 to $825 \mathrm{kWh} / \mathrm{m}^{2}$ per annum, whereas the total value of radiation on such roofs in multi-family development is twice higher than on roofs of the other two areas (Fig. 7).

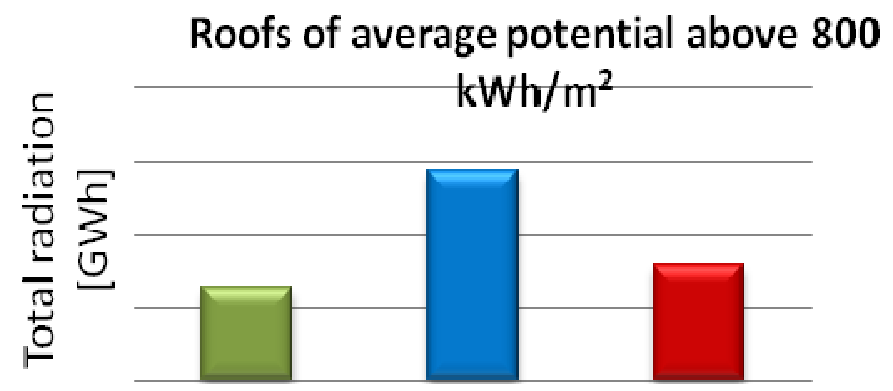

Fig. 7. Total annual solar radiation [GWh] for roofs of average potential above $800 \mathrm{kWh} / \mathrm{m}^{2}$ in three analysed areas

\section{Indicators which characterise buildings of different shapes and roof dimensions}

The next step of the analysis was to check which part of each analysed roof is a surface on which solar radiation exceeds $800 \mathrm{kWh} / \mathrm{m}^{2}$ and if it is large enough to install standard photovoltaic cells. Fig. 8 presents an examples of classification of roof surfaces by their shape, size and solar potential. Raster maps of global radiation of a spatial resolution of $0.5 \mathrm{~m}$ were used in the analysis. 


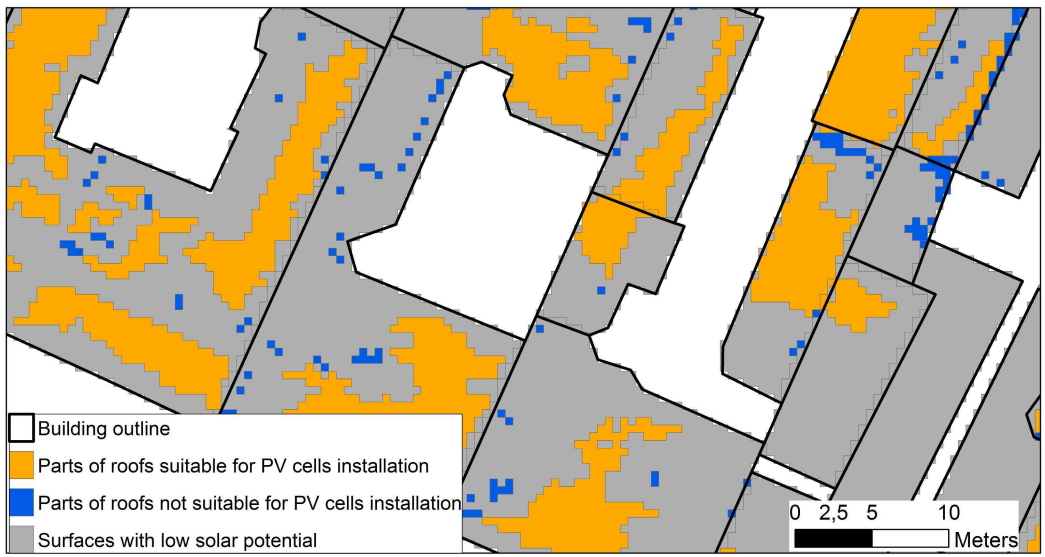

Fig. 8. Pieces of roofs classified as suitable for installation of photovoltaic cells

On the basis of calculated global radiation, uniform roof pieces of a solar potential above $800 \mathrm{kWh} / \mathrm{m}^{2}$, a surface equal to or higher than $1.7 \mathrm{~m}^{2}$ and a shape similar to a rectangular with a shorter side of at least $1 \mathrm{~m}$ were determined for each building roof.

Such selected surfaces were then compared with the total surface of the roofs. As a result, a so-called coverage ratio was obtained as a number between 0 and 1. Table 3 presents results of calculations for three types of housing development.

Table 3. Results of solar potential calculations of fragments (pieces) of building roofs of a potential $\geq 800 \mathrm{kWh} / \mathrm{m}^{2}$ and a required size and shape

\begin{tabular}{|l|c|c|c|}
\cline { 2 - 4 } \multicolumn{1}{c|}{} & $\begin{array}{c}\text { Single-family } \\
\text { housing }\end{array}$ & $\begin{array}{c}\text { Multi-family } \\
\text { housing }\end{array}$ & $\begin{array}{c}\text { Downtown } \\
\text { development }\end{array}$ \\
\hline Number of roofs & 901 & 114 & 1027 \\
\hline Average roof surface in $\mathrm{m}^{2}$ & 51 & 390 & 120 \\
\hline $\begin{array}{l}\text { Average coverage ratio for roof } \\
\text { pieces of a potential } \geq 800 \\
\mathrm{kWh} / \mathrm{m}^{2}\end{array}$ & 0.46 & 0.58 & 0.29 \\
\hline $\begin{array}{l}\text { Average number of pieces on a } \\
\text { roof }\end{array}$ & 1.10 & 1.57 & 1.67 \\
\hline $\begin{array}{l}\% \text { share of roofs in a coverage } \\
\text { ratio above 0.5 }\end{array}$ & $55 \%$ & $70 \%$ & $25 \%$ \\
\hline $\begin{array}{l}\text { Total radiation on pieces of a } \\
\text { potential } \geq 800 \mathrm{kWh} / \mathrm{m}^{2} \text { and } \\
\text { required size and shape [GWh] }\end{array}$ & 20.7 & 27.2 & 38.7 \\
\hline
\end{tabular}


Data presented in Table 3 shows that for downtime development only 25\% of buildings have roofs on which more than half of the surface can be used to install photovoltaic cells necessary to obtain energy. The highest percentage share of such roofs is for multi-family housing development. Total radiation on fragments of roofs of a size and shape suitable for the installation of standard photovoltaic cells is $38,7 \mathrm{GWh}$ for the analysed downtown housing development area. This value is $46.5 \%$ higher than for analogical fragments of roofs within a single-family housing area and $27.4 \%$ higher than for multifamily housing development.

\section{CONCLUSIONS}

The performed analysis has demonstrated that the acquisition of solar energy in municipal conditions strongly depends on the nature and density of development. Multi-family housing areas with high buildings and a relatively low development density are most advantageous in that respect. High density (downtown development) areas have a very large surface of roofs for which total solar radiation is almost 2-3 times higher than in other areas, but their average solar potential is lower than approx. $20 \%$ than in areas of a lower development density.

The shape of building roofs is crucial for obtaining solar energy in urban areas. According to the analysis, the shape of roofs in the historical downtime development area limits the number of buildings on which installation of photovoltaic cells is profitable to $25 \%$.

Taking into account uniform and proper size fragments of roofs of a high solar potential (above $800 \mathrm{kWh} / \mathrm{m}^{2}$ per annum), the average coverage ratio in downtown development is almost twice lower than in the other analysed areas. However, due to the high development density their total potential is $27.4 \%$ $46.5 \%$ greater than in single- and multi-family housing development areas.

With the studies on the solar potential on a yearly basis, it was possible to formulate the relationship between the density and nature of development and the opportunities for obtaining energy from solar systems. Furthermore, it has been demonstrated that the greatest amounts of energy can be generated on buildings of historical downtown development.

\section{ACKNOWLEDGMENTS}

The studies were conducted with instruments provided with financial support as part of the project: 'Implementation of the $2^{\text {nd }}$ Stage of the Regional Innovation Centre' co-finance by the European Regional Development Fund for the 
Regional Operational Programme for the Kuyavian-Pomeranian Province for the Years 2007-2013.

\section{REFERENCES}

1. Brito M.C., Gomes N., Santos T., Tenedorio J.A.: Photovoltaic potential in a Lisbon suburb using LiDAR data. Solar Energy, 86, (2012), 283-288.

2. Choi Y., Rayl J., Tammineedi C., Brownson J. R. S.: PV Analyst: Coupling ArcGIS with TRNSYS to assess distributed photovoltaic potential in urban areas. Solar Energy, 85, (2011), 2924-2939.

3. Chow A., Fung A. S., Songnian Li: GIS Modeling of Solar Neighborhood Potential at a Fine Spatiotemporal Resolution, Buildings, 4, (2014), 195206.

4. De Boeck L., Van Asch S., De Bruecker P., Audenaert A.: Comparison of support policies for residential photovoltaic systems in the major EU markets through investment profitability, Renewable Energy, 87, (2016), $42-53$.

5. Energy Roadmap 2050, Communication from The Commission to The European Parliament, The Council, The European Economic and Social Committee and The Committee of The Regions, $\operatorname{COM}(2011)$ 885, Brussels, 2011.

6. Freitas S., Catita C., Redweik P., Brito M.C.: Modelling solar potential in the urban environment: State-of-the-art review, Renewable and Sustainable Energy Reviews 41, (2015), 915-931.

7. Kopietz-Unger J.: Energetyczny audyt miejski - potrzeby, założenia i schemat, Przegląd budowlany, 12 (2011), 32-37.

8. Mrówczyńska M., Wawer M.: Attempt to prepare a solar cadastre for the town of Zielona Góra, Journal of Civil Engineering, Environment and Architecture, XXXII, 62, 4 (2015), 321-333.

9. Photovoltaic Geographical Information System (PVGIS), Joint Research Centre. Institute for Energy and Transport, (http://re.jrc.ec.europa.eu/pvgis/, access 04.09.2017)

10. Podręcznik dla uczestników szkoleń z wykorzystaniem produktów LIDAR, edit. P. Wężyk, ISOK., Główny Urząd Geodezji i Kartografii, Warszawa 2015.

11. Redweik P., Catita C., Brito M.: Solar energy potential on roofs and facades in an urban landscape, Solar Energy 97, (2013), 332-341.

12. Urząd Regulacji Energetyki, Odnawialne źródła energii, Potencjat krajowy OZE w liczbach (http://www.ure.gov.pl/, access 04.09.2017)

13. Ustawa o odnawialnych źródtach energii z dnia 20 lutego 2015 roku, Dz. U., (2015), p. 478, 2365. 
14. Yearly sum of global irradiation on optimally-inclined surface in Poland, PVGIS, European Communities, (http://re.jrc.ec.europa.eu/pvgis/countries/ europe/g13yopt_pl.png, access 04.09.2017)

\section{STUDIUM WYKORZYSTANIA NARZĘDZI GEOINFORMACYJNYCH W ZRÓWNOWAŻONYM GOSPODAROWANIU ENERGIĄ SŁONECZNA}

\section{Streszczenie}

Efektywne gospodarowanie zasobami to podstawowy element strategii Unii Europejskiej na rzecz wzrostu gospodarczego - „Europa 2020”. Ma ona na celu pobudzanie rozwoju, który będzie inteligentny, zrównoważony i sprzyjający włączeniu społecznemu. Prawidłowe zagospodarowanie terenu korzystnie wpływa na rozwój gospodarczy oraz przyczynia się do poprawy warunków życia mieszkańców. Doskonałym narzędziem pozwalającym skutecznie planować przestrzeń są systemy informacji geograficznej. Technologia GIS umożliwia wykonywanie złożonych analiz, które pozwalają na wszechstronną ocenę środowiska przyrodniczego i przestrzeni zurbanizowanej. Zastosowanie narzędzi GIS pozwala także na ocenę różnych wariantów zagospodarowania terenu w przyszłości. W artykule zaprezentowano wyniki analiz, przeprowadzonych na podstawie NMT i NMPT, których celem była ocena potencjału solarnego wybranego obszaru. Pokazano możliwości wykorzystania powierzchni dachów starej zabudowy fragmentu miasta Bydgoszczy do zamontowania na nich instalacji solarnych.

Słowa kluczowe: odnawialne źródła energii, potencjał solarny, GIS

Editor received the manuscript:20.12.2017 